\title{
Exploring the Convergence of the Mobile Learning Mode in Network Environment and the Traditional Classroom Teaching Mode
}

\author{
https://doi.org/10.3991/ijet.v12i07.7248 \\ Wang Lin \\ Faculty of Educational Science, Zhaoqing University, Zhaoqing, China \\ wlin8117@ 163 .com
}

\begin{abstract}
The mobile network learning mode has been praised by many learners because of the convenience of using mobile phones. At the same time, it has posed great challenges to traditional teaching modes. To make full use of the mobile network learning mode and make up for the traditional classroom teaching mode, we investigated the convergence of these two modes. To this end, we analyzed the reasons for college students' low network learning efficacy. Further, based on China's current mobile network environment, national network policies, and the experience of constructing mobile network learning resources, we practiced mobile network learning in a course on Photoshop. The experiment showed that the mobile learning mode is feasible and that with the proper use of the mobile network environment, teachers can enrich teaching resources in class and raise students' learning efficiency in classroom teaching. To achieve the desired effects of the mobile network learning mode, teachers should pay attention to three factors: the change of the teacher's role in the teaching process, the acquisition of mobile network applications in the new learning mode, and the support of exterior service technologies. Applying this learning mode can provide valuable experience for the transformation of traditional teaching modes.
\end{abstract}

Keywords-mobile network, mobile learning, classroom teaching, convergence

\section{Introduction}

With the development of mobile network technology, people are increasingly accepting the mobile learning mode, which has become an effective way to combine formal and informal classroom study. However, compared to the rapid development of mobile network technology, the convergence of traditional classroom learning and mobile network learning is proceeding very slowly. Today, classroom teaching is unable to dispense with established traditional modes, and it is hindered by inflexible attendance checking systems, slowly updated sets of disciplines, and paper-based testing. Although most teachers use multimedia such as WeChat, QQ, and Microblog, such use has only slightly improved the increasingly alienated teacher-student rela- 
tionship and has failed to radically change student creativity, performance, and learning processes. In 2013, 55 experts from 18 countries noted in the Basic Education Edition of the Horizon Report that "in the next five years, the school will try to adopt both face-to-face and network-based teaching models." [1]

By February 2016, the Higher Education Edition of the Horizon Report had said that "the convergence of formal learning and informal learning" would be among the challenges constraining the application of higher education technology. The maturity of mobile network technology has led to large online educational platforms such as EdX, Coursera, and Udacity, and learners have gradually begun to accept mobile learning, establishing new requirements for classroom teaching. The emergence of new technologies and teaching ideas necessitates the urgent combination of mobile learning and classroom teaching modes. However, the future development of mobile learning will be led astray if technology application is deliberately pursued, the learning efficiency of the mobile learning platform is magnified, and hardware resources are overemphasized. Research on the convergence of mobile network learning and classroom teaching modes requires a clear understanding of the present situation. In this way, we can understand how to correctly use mobile learning platforms and how to change teachers' roles, thereby improving class efficiency and achieving the necessary transition in teaching.

\section{The Present Situation of Researchs}

In China and elsewhere, the maturity of mobile network technology has drawn researchers' attention to informal learning modes. In 2010, Swedish researchers studied the integration of formal and informal learning modes, allowing students to freely use Twitter in class. The results showed that the application of digital technology can enhance classroom teaching efficiency [2]. That study emphasized interaction in classroom teaching but did not systematically design the class and could not record individual student learning processes. From 2012 to 2013, an EU committee sponsored the TRAILER program, in which researchers from seven countries developed an ICTbased service that would help learners identify informal learning behaviors and make every organization in the committee accept the learning results of the service. This program also aimed to make informal learning into a part of individual learning, which would make it possible to mark, identify, and admit learners' informal learning activities [3]. This program focused on the evaluation of informal learning results and did not include the influence of classroom teaching on informal learning.

Most Chinese scholars have emphasized theoretical research on informal learning modes. For example, Xin Ying's 2011 study "Research on Adult Informal Learning" investigated how to facilitate informal adult learning[4]. In the same year, Chai Yangli investigated the current situation of informal learning among college students in the Web 2.0 environment[5].In 2012, Wang Ying's study "Research on and Practice of the Identification of Informal Learning Achievement" considered how to evaluate adults' informal learning results[6].More recently, Guo Hongxia's 2016 paper "The Impact of New Media Environment on the Informal Study of College Students 
and the Countermeasures" proposed measures to improve college students' informal learning in terms of conforming value identification, updating learning concepts, integrating formal learning, improving technology ability, and perfecting selfmanagement[7].Most researchers acknowledge that informal learning poses certain problems, but they have not offered effective solutions or described in detail how informal learning can be integrated into classroom teaching. However, if we properly use mobile network technology, integrate mobile learning into classroom teaching, and encourage teachers and students to achieve role changes in this mode, such a transition can take place quite naturally.

The next section will describe the external environment for integrating learning modes, analyze the major elements influencing students' learning efficiency in terms of network learning efficacy, and establish a learning mode that integrates the mobile network environment into classroom teaching to enhance learning efficiency. Section IV discusses the major elements that influence the effective execution of the proposed learning mode. Finally, section V summarizes the experiment.

\section{$3 \quad$ Methodology}

\subsection{Research on the hardware environment of the integrated learning mode}

University mobile network construction influenced by government policies: In 2004, the State Council issued the "2003-2007 Plan of Actions for Developing Education," emphasizing that universities should reinforce network construction and attach importance to hardware and public service platforms[8]. Then, in 2012, "The Ten-Year Plan for the Development of Educational Informatization (2011-2020)" stipulated the aim to "realize the coverage of broadband networks in all regions and all types of schools.[9]" In June 2016, the Science and Technology Development Center of the Ministry of Education released "Research on the Present Situation of Information Construction in Colleges and Universities in China," which conducted questionnaire surveys at 243 colleges during the period of the 12th Five-Year Plan. The results (found on Sohu, 360 networks, and some university websites) indicated that all colleges and universities had developed network platforms, among which $85 \%$ offered wireless Internet service; 55\% were free while 52\% charged 10-20 yuan per month. Moreover, in terms of educational applications, $80 \%$ of those schools had purchased online teaching platforms, though the application results were unsatisfactory. Overall, 39\% of colleges and universities had updated their teaching platforms, $24 \%$ were planning to change their platforms, and $20 \%$ had no online teaching platforms [10].

Current situation of the construction of mobile network learning resources: "The National Program for Medium and Long Term Educational Reforms and Developments (2010-2020)," issued in 2010 by China's State Council, underlined the importance of "strengthening the exploitation and application of educational resources in superior quality" [11] and stimulating the rapid construction of information resources in higher education. 


\subsection{Research on major elements that influence college students' mobile network learning effect}

To integrate mobile learning and classroom teaching, we must fully account for college students' ability to learn in the mobile network environment and determine the main factors affecting their learning efficacy. In December 2016, the researcher's student Liu Chunfeng conducted a survey on network learning self-efficacy at Zhaoqing University, in which 287 undergraduates filled out questionnaires. The results indicated that the higher one's computer ability, the better one will perform in terms of network learning self-efficacy (Table 1). Students in different grades have different network learning self-efficacy (Table 2). Students in different majors also show significant differences, with science students scoring much higher than liberal arts students.

A comparison of Chinese studies of college students' network learning efficacy indicates that students are capable of online learning (Table 3). Students' learning and self-control ability are directly proportional to their grade. However, their sense of on-

Table 1. Comparative study of students' network learning efficacy in computer operation

\begin{tabular}{|c|c|c|c|c|c|c|}
\hline & & $\mathbf{N}$ & $\begin{array}{c}\text { Mean value } \\
\text { (M) }\end{array}$ & $\begin{array}{c}\text { Standard } \\
\text { deviation (SD) }\end{array}$ & $\mathbf{F}$ & $\begin{array}{c}\text { Signifi- } \\
\text { cance }\end{array}$ \\
\hline \multirow{4}{*}{$\begin{array}{l}\text { Sense of operational } \\
\text { efficacy in network } \\
\text { learning }\end{array}$} & Skilled operation & 83 & 45.66 & 11.62 & \multirow{4}{*}{11.19} & \multirow{4}{*}{.000} \\
\hline & Basic operation & 157 & 42.39 & 7.58 & & \\
\hline & Little operation & 39 & 36.02 & 6.43 & & \\
\hline & Total & 287 & 42.29 & 9.33 & & \\
\hline \multirow{4}{*}{$\begin{array}{l}\text { Sense of information } \\
\text { interaction in network } \\
\text { learning }\end{array}$} & Skilled operation & 83 & 51.33 & 13.65 & \multirow{4}{*}{8.25} & \multirow{4}{*}{.000} \\
\hline & Basic operation & 157 & 48.15 & 7.93 & & \\
\hline & Little operation & 39 & 41.79 & 10.05 & & \\
\hline & Total & 287 & 48.06 & 10.60 & & \\
\hline \multirow{4}{*}{$\begin{array}{l}\text { Sense of concept inter- } \\
\text { action in network } \\
\text { learning }\end{array}$} & Skilled operation & 83 & 20.55 & 5.22 & \multirow{4}{*}{5.05} & \multirow{4}{*}{.002} \\
\hline & Basic operation & 157 & 19.01 & 3.92 & & \\
\hline & Little operation & 39 & 17.25 & 5.04 & & \\
\hline & Total & 287 & 19.21 & 4.59 & & \\
\hline \multirow{4}{*}{$\begin{array}{l}\text { Sense of self- } \\
\text { management efficacy }\end{array}$} & Skilled operation & 83 & 15.22 & 3.15 & \multirow{4}{*}{3.46} & \multirow{4}{*}{.017} \\
\hline & Basic operation & 157 & 14.44 & 2.42 & & \\
\hline & Little operation & 39 & 13.64 & 2.28 & & \\
\hline & Total & 287 & 14.56 & 2.67 & & \\
\hline \multirow{4}{*}{$\begin{array}{l}\text { Sense of general effica- } \\
\text { cy }\end{array}$} & Skilled operation & 83 & 41.91 & 8.40 & \multirow{4}{*}{7.56} & \multirow{4}{*}{.000} \\
\hline & Basic operation & 157 & 39.00 & 5.80 & & \\
\hline & Little operation & 39 & 35.76 & 7.01 & & \\
\hline & Total & 287 & 39.44 & 7.09 & & \\
\hline \multirow{4}{*}{$\begin{array}{l}\text { Sense of network } \\
\text { learning efficacy }\end{array}$} & Skilled operation & 83 & 174.69 & 37.56 & \multirow{4}{*}{10.48} & \multirow{4}{*}{.000} \\
\hline & Basic operation & 157 & 163.01 & 22.95 & & \\
\hline & Little operation & 39 & 144.48 & 25.57 & & \\
\hline & Total & 287 & 163.59 & 29.82 & & \\
\hline
\end{tabular}


Paper-Exploring the Convergence of the Mobile Learning Mode in Network Environment and the...

Table 2. Comparative study of students' network learning efficacy in different grades

\begin{tabular}{|c|c|c|c|c|c|c|}
\hline & & $\mathbf{N}$ & $\begin{array}{c}\text { Mean } \\
\text { value (M) }\end{array}$ & $\begin{array}{c}\text { Standarddeviation } \\
\text { (SD) }\end{array}$ & F & $\begin{array}{l}\text { Signifi- } \\
\text { cance }\end{array}$ \\
\hline \multirow{4}{*}{$\begin{array}{l}\text { Sense of opera- } \\
\text { tional efficacy in } \\
\text { network learning }\end{array}$} & Freshman & 41 & 39.68 & 11.210 & \multirow{4}{*}{2.073} & \multirow{4}{*}{.010} \\
\hline & Sophomore & 60 & 41.90 & 7.151 & & \\
\hline & Junior & 70 & 41.82 & 8.622 & & \\
\hline & Senior & 116 & 43.70 & 9.868 & & \\
\hline \multirow{4}{*}{$\begin{array}{l}\text { Sense of infor- } \\
\text { mation interaction } \\
\text { in network learn- } \\
\text { ing }\end{array}$} & Freshman & 41 & 45.02 & 14.462 & \multirow{4}{*}{1.745} & \multirow{4}{*}{.0158} \\
\hline & Sophomore & 60 & 48.15 & 7.489 & & \\
\hline & Junior & 70 & 47.68 & 9.628 & & \\
\hline & Senior & 116 & 49.36 & 10.847 & & \\
\hline \multirow{4}{*}{$\begin{array}{l}\text { Sense of concept } \\
\text { interaction in } \\
\text { network learning }\end{array}$} & Freshman & 41 & 17.78 & 5.858 & \multirow{4}{*}{1.723} & \multirow{4}{*}{.016} \\
\hline & Sophomore & 60 & 19.66 & 3.573 & & \\
\hline & \begin{tabular}{|l|} 
Junior \\
\end{tabular} & 70 & 19.14 & 4.304 & & \\
\hline & Senior & 116 & 19.52 & 4.678 & & \\
\hline \multirow{4}{*}{$\begin{array}{l}\text { Sense of self- } \\
\text { management } \\
\text { efficacy }\end{array}$} & Freshman & 41 & 14.29 & 3.565 & \multirow{4}{*}{.813} & \multirow{4}{*}{.048} \\
\hline & Sophomore & 60 & 14.20 & 1.875 & & \\
\hline & Junior & 70 & 14.82 & 2.642 & & \\
\hline & Senior & 116 & 14.68 & 2.688 & & \\
\hline \multirow{4}{*}{$\begin{array}{l}\text { Sense of general } \\
\text { efficacy }\end{array}$} & Freshman & 41 & 38.39 & 9.107 & \multirow{4}{*}{2.065} & \multirow{4}{*}{.010} \\
\hline & Sophomore & 60 & 39.20 & 5.091 & & \\
\hline & \begin{tabular}{|l|} 
Junior \\
\end{tabular} & 70 & 38.28 & 7.122 & & \\
\hline & Senior & 116 & 40.63 & 7.062 & & \\
\hline \multirow{5}{*}{$\begin{array}{l}\text { Sense of network } \\
\text { learning efficacy }\end{array}$} & Freshman & 41 & 155.17 & 40.197 & \multirow{5}{*}{2.015} & \multirow{5}{*}{.011} \\
\hline & \begin{tabular}{|l} 
Sophomore \\
\end{tabular} & 60 & 163.11 & 20.111 & & \\
\hline & \begin{tabular}{|l|} 
Junior \\
\end{tabular} & 70 & 161.77 & 27.741 & & \\
\hline & Senior & 116 & 167.91 & 30.565 & & \\
\hline & Total & 287 & 163.59 & 29.822 & & \\
\hline
\end{tabular}

line learning self-efficacy is in the middle or at a lower level. Whether they are undergraduates or postgraduates - and no matter whether they attend top universities or local colleges - students tend to avoid problems in network learning, thus decreasing their network learning efficacy. Moreover, for students who have received years of traditional education, pure mobile learning experiences can hardly raise their network efficacy. Clearly, there will be a great leap forward and apparent improvement in college students' learning efficacy if integrated mobile learning and classroom teaching is established based on student experiences with the support of teachers' guidance as well as the exchange of ideas among students.

\subsection{Constructing a learning mode based on the convergence of mobile network environments and classroom teaching}

Based on previous data, we can say that mobile Internet environments have been developed at all universities and colleges in China. Multimedia teaching environments 
Paper-Exploring the Convergence of the Mobile Learning Mode in Network Environment and the...

Table 3. Comparative study of students' network learning efficacy in different grades

\begin{tabular}{|c|c|c|c|}
\hline Year & $\begin{array}{c}\text { Research- } \\
\text { er(s) }\end{array}$ & Research range & Results \\
\hline 2011 & $\begin{array}{l}\text { Xie Youru, } \\
\text { et al }\end{array}$ & $\begin{array}{l}\text { Graduate students of } \\
\text { Huazhong University of } \\
\text { Science and Technology, } \\
\text { South China University } \\
\text { of Technology, Hebei } \\
\text { Normal University, and } \\
\text { Southwest University }\end{array}$ & $\begin{array}{l}\text { Students' personal conditions can influence their network } \\
\text { self-learning efficacy. } \\
\text { A positive correlation exists between college students' } \\
\text { online self-learning efficacy and their coping and shelving } \\
\text { strategies; a negative correlation exists between self- } \\
\text { learning efficacy and avoidance strategies. } \\
\text { A sense of computer anxiety negatively correlates with } \\
\text { self-learning efficacy. } \\
\text { Network experience positively correlates with students' } \\
\text { self-learning efficacy[12]. }\end{array}$ \\
\hline 2012 & Lihao & $\begin{array}{l}\text { Postgraduate students in } \\
\text { reading at Shanxi Nor- } \\
\text { mal University }\end{array}$ & $\begin{array}{l}\text { Students today have low self-efficacy, and individual } \\
\text { differences are significant. } \\
\text { To promote network self-learning efficacy, it is necessary } \\
\text { to pay attention to online learning efficacy, especially the } \\
\text { effects of online learning on individual information- } \\
\text { exchange efficacy[13]. }\end{array}$ \\
\hline 2015 & Qiu Nating & $\begin{array}{l}\text { Graduate students at } \\
\text { Nanjing University of } \\
\text { Posts and Telecommuni- } \\
\text { cation }\end{array}$ & $\begin{array}{l}\text { College students' online learning efficacy is not high. } \\
\text { There are great differences in gender, grade, and comput- } \\
\text { er operation level. } \\
\text { A significantly positive correlation exists between self- } \\
\text { efficacy and study performance in network learning } \\
\text { environments[14]. }\end{array}$ \\
\hline
\end{tabular}

can be guaranteed, experience with mobile learning resources has accumulated, and there are enough designers to develop network learning platforms. Thus, the hardware conditions necessary for the convergence of mobile and classroom learning modes are mature.

Based on the current mobile network situation and students' experiences in Chinese colleges, a converged learning mode can be constructed. Such a mode would use classroom teaching to guide students to acquire principal knowledge, assign teaching tasks for relative units, categorize students for later study guidance, and conduct thematic teaching based on feedback from mobile network learning data. Aside from offering students learning materials and promoting mutual communication, mobile network learning can also record students' learning data to provide feedback to teachers and students. Learning resources should be previously designed and planned by teachers and given to providers of learning service technology who are responsible for the construction of mobile learning platforms, thus enabling students to complete the study of related courses (Fig. 1).

Based on the converged learning mode of a mobile network environment and classroom teaching, we set up a network learning platform for a course in Photoshop to test the learning mode (Fig. 2 and Fig. 3). In the process of using that platform, and in the course of classroom teaching, the major elements that influence students' learning effects are further investigated. 


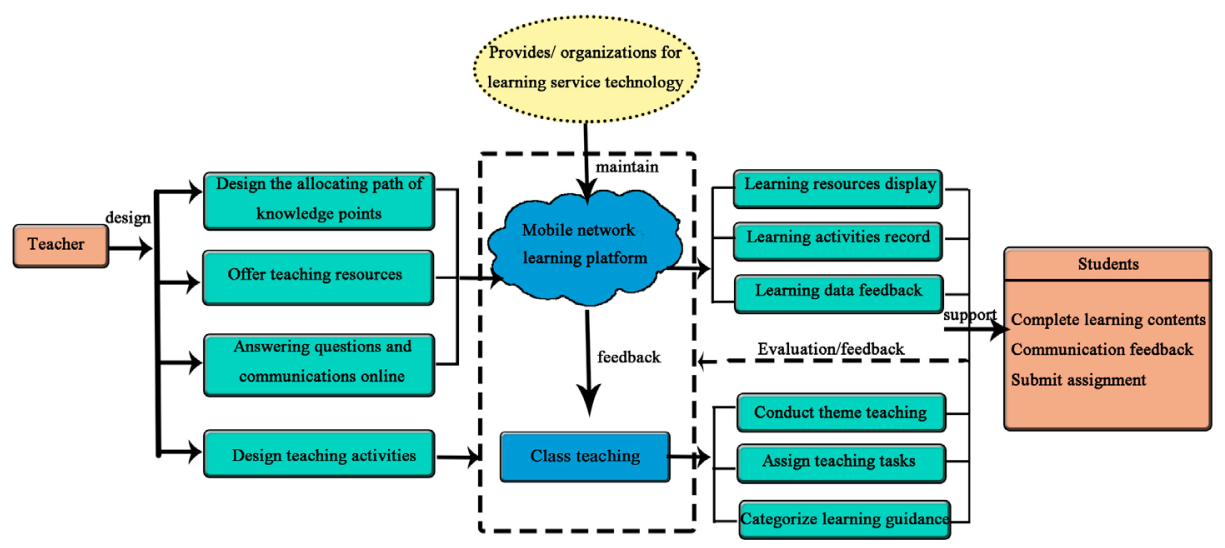

Fig. 1. Converged teaching mode for mobile learning and classroom teaching

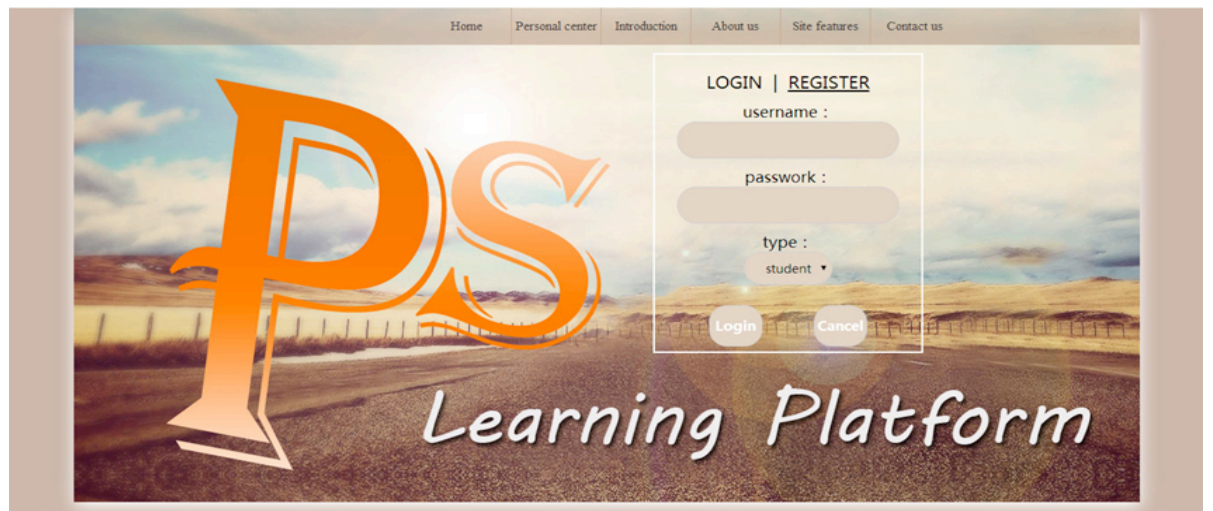

Fig. 2. First page of the mobile network learning platform

\section{Result Analysis and Discussion}

Through teaching practice, it was found that three factors influence the effective execution of the converged teaching mode: 1) the change in the teacher's role, 2) the correct location of mobile network environment applications, and 3) support from the necessary exterior technological services.

\subsection{Change in the teacher's role}

Policies have been made regarding Information Technology (IT) training for teachers in China's middle and primary schools, but IT training for university teachers has not received sufficient attention. This contradicts the trend toward exploring new teaching modes. Therefore, the new converged learning model aims to not only improve teachers' technological abilities but also change their role in the new learning mode. 


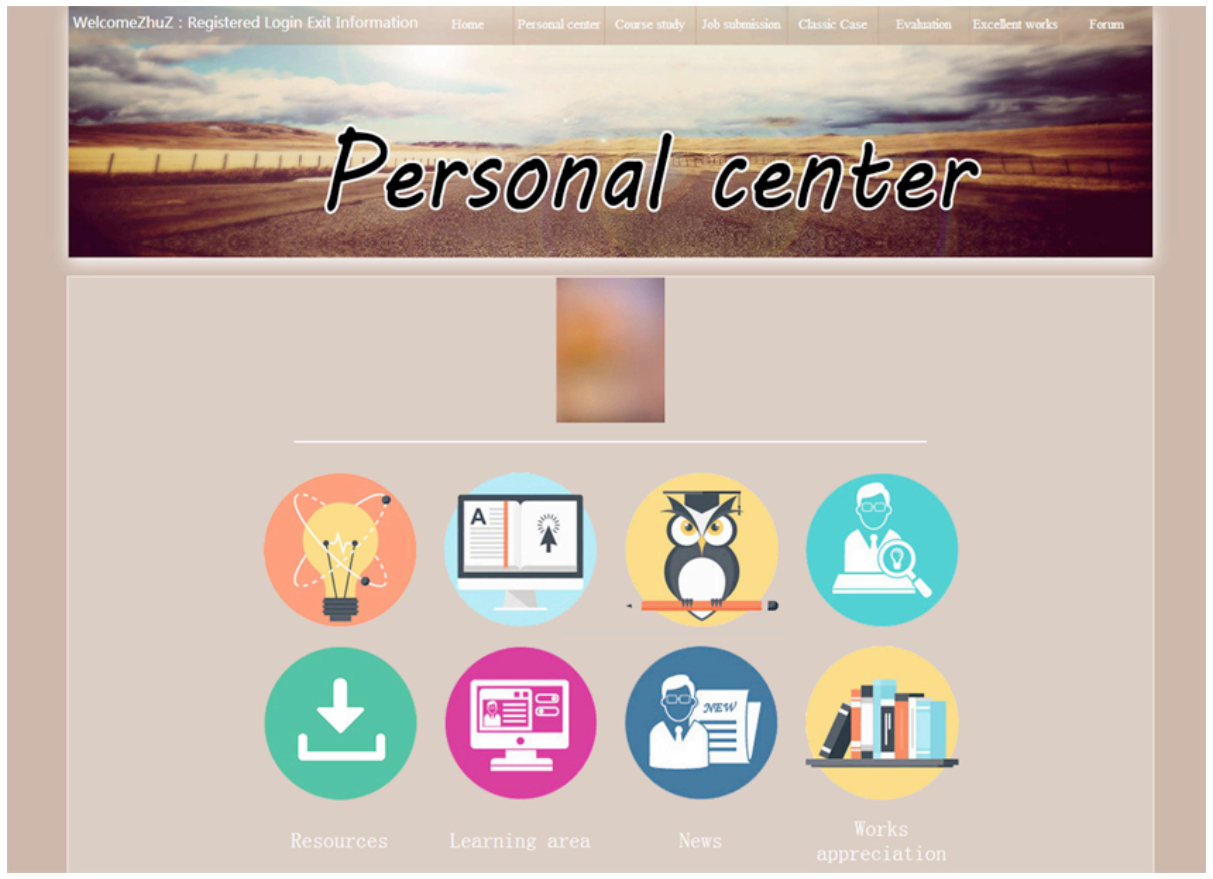

Fig. 3. Individual learning platform center

Teachers: Direct participants in constructing the knowledge space: The way teachers impart knowledge to students in traditional classroom teaching is like drawing a straight line between two points on a piece of paper, which makes it seem like the shortest and most direct way to deliver knowledge. The appearance of mobile network technology endows knowledge with a sense of time and space, and students can overcome the limitations of class learning and obtain information through mobile networks[15].Teachers are direct participants in constructing the knowledge space.A course is a complete system. Without teachers' participation, constructing course resources is empty and soulless, and the network platform is isolated. If its operation only depends on a student's learning initiative, what would be the point? What would be the point of convergence learning? Thus, teachers must be involved in the whole process of exploiting resources in mobile network environments.

Teachers: Regulators of teaching processes: Teachers must be the regulators of teaching processes. With the intervention of mobile network environments, teachers should be able to control the progress of teaching and elaborately design teaching activities. Meanwhile, they should also regulate students' learning processes. The application of mobile networks in teaching can help teachers discover problems in teaching activities and redirect students who deviate from the learning track.

Teachers: Facilitators in students' learning processes: In traditional classroom teaching, teachers are absolute controllers and authorities in the teaching process; this is quite different from the concept of regulator mentioned above. Teachers in traditional settings usually add subjective emotions to the teaching process without con- 
sidering students' reactions. Australia's elastic learning handbook notes that facilitators of online learning are also promoters who can help students become interested in the learning process, give feedback on learning techniques after receiving information during the learning process, help learners, manage online discussions, and facilitate interpersonal relationships[16]. Thus, while facilitators are not necessarily teachers, teachers are facilitators in the new learning mode

\subsection{Location of mobile network environment applications}

The development of network technology leads to changes in learners' learning methods. However, this does not mean that as long as this technology exists between teachers and students, the best teaching result can be achieved. The network learning efficacy of college students indicates that they do have the ability to perform network learning. The fact that the expected learning results have not been obtained is attributable not only to students' low self-control ability but also to their low sense of efficacy caused by a lack of teacher guidance. Therefore, it is necessary to relocate the applications of mobile network environments in the converged learning mode. First, students should make full use of the mobile network environment to form their own learning path. In traditional classroom teaching, students' learning paths are uniform in nature. In such classes, no matter how many students there are, the teacher must ensure that the teaching objectives for a certain period are completed, and then he or she must move on to the next objective, regardless of whether all students have mastered the material. Mobile learning environments can change this phenomenon and foster students' individuality. Teachers can categorize knowledge points, important points, difficult points, and testing points based on levels of difficulty and complexity, and students can choose the content of their study. Thus students can form their own learning paths, and teachers can identify students' interests and possible problems by observing what knowledge points they choose. Second, mobile network environments can help realize mutual communication. Third, mobile network environments can be used to obtain data on students' learning processes. We have the initiative to record students' learning activities based on their register times, online learning times, and click rates. We have records of students' participation in asking questions, giving answers, and turning in homework. We can identify students' learning trends from click rates and answering frequency on certain topics, or from the number of students who hand in their homework and the number of times each student has turned in homework. All these data can provide a basis for updating learning resources in the future. Fourth, mobile network environments can provide a prognosis for classroom teaching. In other words, teachers can discover whether students have mastered the knowledge points of a certain unit based on the pass rate for a test on that unit in the online learning platform. They can also identify the learning progress of each student and his or her learning path, thus forming ideas to modify teaching plans. 


\subsection{Necessary external technological support}

The low use rate and frequent change of network learning platforms in China's universities and colleges is attributable to teachers' limited participation in constructing network learning platforms as well as the lack of support from network learning service mechanisms in the process of using platforms. In addition, external technological support plays a significant role in protecting and maintaining the data collected from teachers, students, and mobile learning platforms. As for teachers, they can quickly access students' individual data and make technological suggestions for the construction of mobile learning resources. As for students, they can get learning forewarnings and suggestions for selecting courses, and can search for records of their learning growth at any time. With the support of learning service mechanisms, mobile learning platform data can be efficiently used and maintained. The rate of using platforms will be increased, the frequency of changing platforms will be reduced, and a better mobile learning effect will be guaranteed.

\section{Conclusions}

To make full use of the respective advantages of the mobile network learning mode and the traditional classroom teaching mode - and to persuade learners to discard the idea of transforming traditional classroom teaching by using the hardware environment only - this study first analyzed the common reasons for college students' low learning efficacy in the mobile network environment. Then, it analyzed the external environmental conditions needed for the new learning mode. Finally, it tested the new learning mode using a course in Photoshop and arrived at the following conclusions.

1. Establishing this new learning mode can effectively solve problems such as low network learning efficacy, thereby avoiding problems, or reluctantly tackling them, in the network learning process.

2. Relocating mobile network environment applications in the new learning mode can enhance a course system's completeness and help record students' individual learning experiences. The resources provided by the platform can greatly elevate teaching efficiency and compensate for shortcomings in traditional classroom teaching.

3. The new learning mode can help teachers change their roles and gradually transform the established traditional teaching mode. Such change requires time, and it is by no means certain that using a new technique will yield good teaching results. It requires trial and error on the part of teachers, as well as adaptation to changing roles. In this way, teachers can maintain their profession in the future.

This research on the convergence of mobile network environments and classroom teaching modes aims to enable teachers and students to accept a new teaching mode in the present hardware environment. In the experiment conducted in this study, the new learning mode raised the learning efficacy of students but also increased teachers' after-class work. Therefore, in executing the learning mode in the future, we 
Paper-Exploring the Convergence of the Mobile Learning Mode in Network Environment and the...

should seek new ways to measure and evaluate teachers' performance. Further, we should include teachers' participation in network learning platforms to encourage them to devote themselves to reforming the new learning mode.

\section{Acknowledgment}

This research was supported by the 2016 General Educational Reform Project of the Educational Bureau of Guangdong Province.

\section{$7 \quad$ References}

[1] L.Johnson and others,New Media Alliance Horizon Report(2013 Basic Education Edition), trans. Zhang Tiedao and others Journal of Beijing Radio \& TV University 2013 vol. S1, pp. $31-53+80$.

[2] KW Lai, F.Khaddage, and G Knezek, Blending Student Technology Experiences in Formal and Informal Learning,Journal of Computer Assisted Learning 2013, vol. 29(5),pp.414425. https://doi.org/10.1111/jcal.12030

[3] Francisco J.and others, Tagging,Recognition,Acknowledgment of Informal Learning Experiences-A Methodology to Make Learners' Informal Learning Activities Visible to the Institutions, Journal of Universal Computer Science,2013, vol. (19),pp.1661-1683.

[4] XingLei,Research on Adult Informal Learning,Shanghai:East China Normal University,2011.

[5] Chai Yangli, Research on the Informal Learning Status of College Students in Web2.0 Environment and Countermeasures Against the Negative Effects,E-Education Research 2011, vol. (12),pp.63-68.

[6] WangYing, Research on and Practice of the Identification of Informal Learning Achievement, China Audio-Visual Education 2012, vol. (1), pp.33-37.

[7] Guo Hongxia, On the Impact of New Media Environment on the Informal Study of College Students and the Countermeasures, China Electrotechnical Education 2016, vol. (3), pp.27-32.

[8] 2003-2007 Plan of Actions for Developing Education, Retrieved from http://www.edu.cn/ 20040325/3102277.shtml [2013-12-12].

[9] Ten-Year Plan for the Development of Educational Informatization (2011-2020), Retrieved from http://www.moe.gov.cn/publicfiles/business/htmlfiles/moe/s3342/201203/133 322.html [2013-12-12].

[10] Analysis of the Present Situation of Informational Construction in Colleges and Universities in China, Retrieved from http://nic.dlou.edu.cn/d8/a9/c4612a55465/page.htm [201611-09].

[11] National Program for Medium and Long Term Educational Reforms and Developments (2010-2020), Retrieved from http://www.gov.cn/jrzg/2010-07/29/content1667143.htm [2013-12-12].

[12] Xie Youru and others, On the Structure, Influencing Factors and Training Strategies of Self-Efficacy of College Students in Network Learning,E-education Research 2011, vol. (10) ,pp.30-34.

[13] Lixu, A Study on the Self-Efficacy of College Students' Network Learning from the Perspective of Teaching-Learning Interaction, Shanxi, Shanxi Normal University, 2012.5. 
Paper-Exploring the Convergence of the Mobile Learning Mode in Network Environment and the...

[14] Qiu Nating, Research into the Influence of College Students' Self-Efficacy on Their Learning Efficiency in the Network Learning Environment, Nanjing, Nanjing University of Posts and Telecommunications 2015.3.

[15] Wangling, Analysis of Barriers Against the Entry of Handheld Mobile Terminals into Class, Gummi Fasern Kunst 2016, vol.15, pp:2278-2283.

[16] Australian Flexible Learning Framework Quick Guides Series,Effective Online Facilitation(Version2.00), Retrieved from http://flexiblelearning.net.au/guides/facilitation.html.

\section{Author}

Wanglin is a lecturer in Faculty of Educational Science, Zhaoqing University, Zhaoqing, China, 526061 (wlin8117@163.com).

Article submitted 20 May 2017. Published as resubmitted by the author 27 June 2017. 